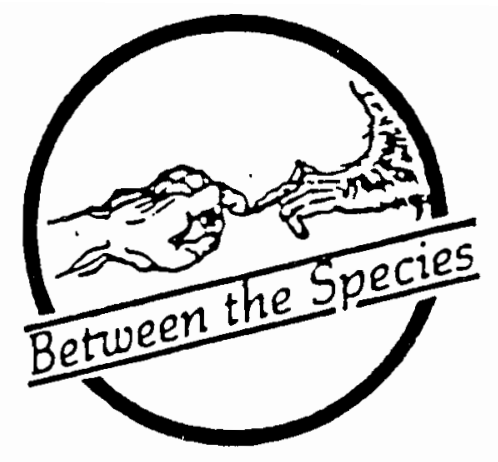

\author{
Stephen T. Newmyer \\ Duquesne University
}

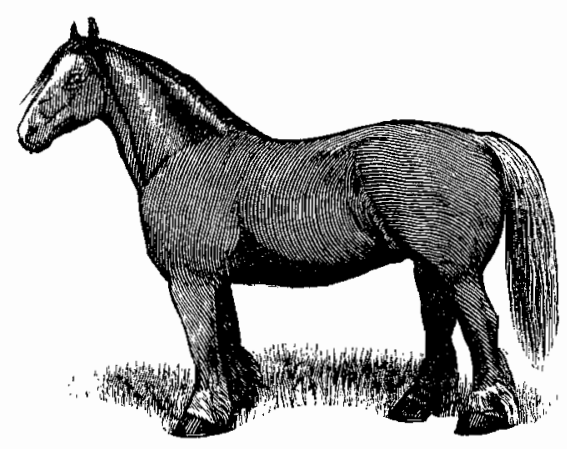

In 1965, English novelist and essayist Brigid Brophy published an article in the London Sunday Times that would exercise a profound influence on the crusade for better treatment of animals in Britain and the United States. In this brief article, entitled simply "The Rights of Animals," Brophy touched upon a number of points that were to become central to the arguments in defense of animals formulated by subsequent representatives of the animal rights movement. ${ }^{1}$ Indeed, Richard D. Ryder, one of the most prominent historians of the movement, judges Brophy's article to have been instrumental in inspiring the rebirth of interest in this issue after decades, if not centuries, of neglect and indifference. Ryder considers the resurgence of interest in the status of animals in the 1960's, as exemplified by Brophy's article, to be a corollary to the anti-sexism and anti-racism crusades of that period as well as an expression of the return-to-nature philosophy of the hippie culture of that decade. ${ }^{2}$ What impresses one in accounts like that of Ryder is the persistent tendency of animal rights advocates to regard a serious concern for the lot of animals as a distinctly modern phenomenon whose philosophical position was formulated only in the past few decades, while arguments put forward by

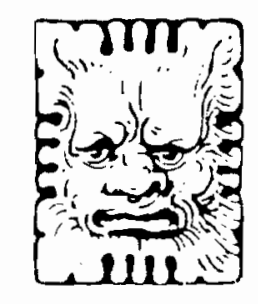

\title{
HISTORY OF IDEAS
}

earlier philosophers in defense of animals are either ignored or summarily dismissed in most recent historical accounts of the growth of human concern for nonhuman species. In particular, this prejudice of contemporary moral philosophers has caused the sometimes profound arguments on the duties of human beings toward other species that appear in certain Greek writers to be largely overlooked. ${ }^{3}$ While it would be absurdly anachronistic to maintain that a philosophy of "animal rights" in a modern sense of that phrase can be traced to classical culture, a concern for the welfare of animals is clearly in evidence in some ancient writers whose arguments in defense of animals at times reveal striking foreshadowings of those developed in contemporary philosophical inquiries into the moral status of animals. This study examines an anticipation, in the animal-related treatises of Plutarch, in particular in his De sollertia animalium (On the Cleverness of Animals), of one of the more controversial arguments marshalled today in defense of animals, that which is commonly termed the argument from marginal cases. ${ }^{4}$ This argument maintains that it is wrong for humans to exploit animals in the belief that only humans are capable of rationality or feeling or perhaps the use of language. These capabilities are not in fact possessed to the same degree by all humans, including, for example, such "marginal cases" as infants, the mentally feeble, or perhaps the severely physically handicapped.

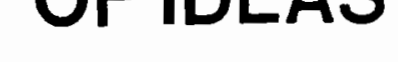


Conversely, science daily furnishes new evidence that at least some species of animals have such capabilities in a higher degree than do the marginal cases of humans. ${ }^{5}$ If one were to lower the standards of human consideration to protect the rights of all sentient humans, that is, all humans capable of feeling pain, one would still have to protect the rights of many animals who certainly possess such sentience, at least to the degree that do marginal humans. One does not normally deny that marginal humans possess such basic rights as the right to life. Consequently, one cannot justly deny to animals who possess the capabilities of marginal humans those rights that are normally accorded to such classes of humans. ${ }^{6}$

In three treatises included in his Moralia, Plutarch set forth his position on the proper treatment owed by humans to animal creation. ${ }^{7}$ The longest and most carefully argued of these, the dialogue De sollertia animalium, explores the question of whether landdwelling or sea-dwelling creatures are more clever. No conclusion is reached, and one has the impression that Plutarch means to suggest that both types are equally intelligent. The incomplete treatise De esu carnium (On the Eating of Flesh) presents a case for vegetarianism on moral and hygienic grounds. ${ }^{8}$ Finally, the brief dialogue Bruta animalia ratione uti (That Beasts Are Rational), also known as Gryllus ('Porker') from the name of one of the interlocutors, envisions a visit by Odysseus to one of Circe's pig-converts who declines the hero's offer to persuade the witch to reconvert him to human form, on the grounds that animals are in all respects superior to humans, possessing every virtue of humans but none of their lusts and excesses. ${ }^{9}$ While these three treatises differ widely in technique and mood, there runs through them a common theme: that animals are both sentient and rational, and because of that fact, humans have no justification for mistreating or exploiting them.

Plutarch's attempt to prove the rationality of animals was motivated by his desire to counter the Stoic position that animals cannot reason and therefore do not merit human concern. ${ }^{10}$ It was impossible, according to the Stoics, for human beings to act unjustly toward creatures that do not understand morality and therefore cannot share the values of human beings. In his survey of the Stoic ethical system, Cicero specifically mentions the alleged lack of rationality in animals that formed the cornerstone of the Stoic case against them (De officiis [On Duties] 1.50): neque ulla re longius absumus a natura ferarum, in quibus inesse fortitudinem saepe dicimus, ut in equis, in leonibus, iustitiam, aequitatem, bonitatem non dicimus; sunt enim rationis et orationis expertes. ("In no respect are we further removed from beasts, in whom we often say that there is courage, as in the case of horses or lions; but we do not say that there is in them justice, equity or goodness; for they are without reason and speech"). ${ }^{11}$ Cicero also informs us that the Stoic Chrysippus denied the possibility of justice between humans and animals (De finibus [On Moral Ends] 3. 67): sed quomodo hominum inter homines iuris esse vincula putant [Stoici], sic homini nihil iuris esse cum bestiis. praeclare enim Chrysippus cetera nata esse hominum causa et deorum, eos autem communitatis et societatis suae, ut bestiis homines uti ad utilitatem suam possint sine iniuria. ("But in the same way as [the Stoics] think that there exist the bonds of right between men and men, so do they feel there is no bond of right with the beasts. For Chrysippus has well observed that other things were born for the sake of men and gods, while men and gods exist for their own society and fellowship, so that men may use beasts for their advantage without injustice").

According to Stoic teaching, the irrationality of animals was a consequence of the defective nature of the animal soul. While it is clear from the extant fragments of Chrysippus that the Stoics were willing to allow that animals have souls that are in some particulars not unlike those of human beings,,$^{12}$ they detected a flaw in the animal soul that ultimately prevented animals from rising above merely instinctual behaviors. The Stoics isolated eight parts of both the human and the animal soul, the eighth part of which they termed the "governing principle." This sends out currents of breath, from the heart to the rest of the human or animal body that lead to impulses and other sorts of behaviors. According to the Stoics, animal behaviors consist exclusively of impulses that may be considered self-interested, or well-disposed only to the animals themselves. Animals consequently make decisions that benefit only themselves, such as the quest for food or the avoidance of pain. ${ }^{13}$ While human beings have at birth a soul not unlike that of the animal, the human soul in time demonstrates reason, which allows humans to rise above self-interested behaviors and to have concern for other rational creatures. Since animals cannot rise to the level at which they can become aware of moral duty toward other rational creatures, humans cannot have duties toward them. ${ }^{14}$ 
Plutarch countered this Stoic assertion of the irrationality of animals, with its important consequences for the Stoic denial of the need for human concern for animals, by noting, among other things, that the Stoics had in fact made no effort to prove their assertion, with which other philosophers would not agree (De sollertia animalium 964C): "How is it right for them to assert that in their discussion about animals and justice, when it is neither generally accepted nor otherwise proven?"15 To refute the Stoic position, Plutarch cites, throughout his three animal-related treatises, examples of animal behaviors that seem to argue for rationality in animals. His examples are derived in large part from such works as Aristotle's Historia animalium (History of Animals) and De generatione animalium (Generation of Animals), the now-lost zoological treatises of Theophrastus, and the dialogues of Plato, and sourcehunting critics have often observed that his examples are mere commonplaces drawn from the stockpile of the sometime naive reflections of Greek natural philosophy that do not suggest personal study on Plutarch's part. ${ }^{16}$ For example, both his observation that the mongoose covers its body in mud to protect itself from the bite of its enemy the crocodile (De sollertia animalium 966D), and his anecdote that an aged and "retired" mule was once known to have encouraged younger mules in their labors (De sollertia animalium 970B), are derived from Aristotle's Historia animalium (612A and 477B). Yet the mere identification of Plutarch's sources overlooks the fact that a significant number of Plutarch's examples are chosen to develop his thesis that in some aspects of intelligence, demeanor and character, animals equal or outstrip human beings, a proposition that is, at least in part, implicit in the argument from marginal cases. This idea is set forth at length in a light-hearted fashion by the pig-philosopher Gryllus in the dialogue of that name. The thoughtful pig observes, for example, that animals are more just than are human beings, for they never seek to enslave other animals (987B), and he argues that animals exceed humans in courage, since while male and female animals fight equally fiercely, female humans seek to avoid battle (987F-988A). Moreover, animal intelligence (991D) in some respects exceeds that of humans because animals have from birth all skills needed for a successful life, while humans must cultivate their intelligence to guide them in a useful direction. Finally, animals more frequently display temperance than do humans, for animals are far less likely to overeat than humans, and do not seek luxurious housing or other possessions as do humans (989B-F). Gryllus ends his catalogue of animal excellences by stating his amazement that he had ever allowed himself to be convinced when human that only humans possess reason and sensation (992C): "Having entered into this body, I am amazed at the arguments by which I was convinced by the sophists to think that all creatures excepting man are without reason and sense." By "sophists," Gryllus probably means the Stoics, against whom the entire dialogue is directed. Plutarch uses a similar argument from animal perception and intelligence to oppose the eating of meat in the treatise De esu carnium (997E), where he praises Pythagoras and Empedocles for enjoining humans to avoid eating animals. ${ }^{17}$

The treatise $D e$ sollertia animalium presents Plutarch's most elaborate defense of the proposition that animals can reason and have sentience. Before the interlocutors Aristotimus and Phaedimus offer a lengthy catalogue of examples of animal rationality (966B-985D), their friends Soclarus and Autobulus set forth some theoretical considerations on animal rationality (960B-961F) that lead to Plutarch's anticipation of the argument from marginal cases (962A-D). Autobulus observes that that which is irrational is soulless while that which has a soul is sentient, and even the Stoics do not deny that animals have souls (960C-D). He mentions approvingly a work by the Peripatetic Strato in which that philosopher had demonstrated that it is impossible for any creature to have sensation without some degree of intellectual activity (961 A), and he delights in catching up the Stoics in a self-contradiction. ${ }^{18}$ Why, he asks (961D), do they bother to punish their dogs and horses if not because they expect them to alter their behavior, which is only possible if the creatures can reflect on the purpose of their chastisement? They seek thereby to create in their animals a feeling of repentance, which, as the Greek word implies, entails reflection.

While he is tempted to accept Autobulus' arguments on animal rationality, Soclarus states that he still considers it the principal failing of animals, among their many other shortcomings, that they do not purposefully aim toward virtue, which is the proper activity of reason. He confesses himself at a loss as to why nature would have given the beginnings of reason to creatures that cannot demonstrate the absolute fullness of reason (962A): "On examining their many other failings, I note that of virtue, toward which reason itself exists; nor do 
I observe clear progress toward it, nor inclination. I am at a loss as to how nature gave them the beginning of it, when they could not arrive at its perfection."

In his reply to Soclarus, Autobulus posits a situation in which the claims of animals to fair consideration by humans are defended by analogy with the claims of a "marginal" class of humans, namely slaves. He observes that those who see no difference between the virtue of a Socrates or a Plato and that of a slave would likewise fail to see that the virtue of an animal is imperfect rather than nonexistent (962B):"But look at this too: is it not ridiculous to keep saying that persons like Socrates and Plato take part in vice no less evil than does any slave, and that they are just as foolish and intemperate and unjust, and at the same time to criticize the impure and imperfect virtue of animals as absence of virtue and not as its weakness and lack of perfection?" In Autobulus' view, one may speak of degrees of virtue, and these degrees are directly proportional to the reasoning capacities of the individuals in question. Certain classes of living things are not by nature designed to receive perfect reason nor, in consequence, to exhibit perfect virtue, but it is not correct, in his view, to conclude that those creatures who do not possess perfect reason do not possess reason at all, for every living creature possesses reason (962C): "There is a portion of reason in all living creatures." While animals, like slaves, fall into the class of those who are not born to receive perfect reason, yet both have some reason and therefore some virtue. What distinguishes a slave from a Socrates, or an animal from a human being, is the degree to which that innate reason is cultivated through training and education (962C): "For reason is inborn from nature, but genuine and complete reason arises from practice and education." Such training and education lie outside the experience of a slave or of an animal, and the virtue of each must remain rudimentary. Yet a slave, even if he can never be a Socrates, has some claim on human sympathy since he shares to some degree the virtue of a Socrates because he can reason to some degree. Not every rational creature, after all, has the perfection of every virtue (962D): "Hence not every creature endowed with reason has to the same degree the perfection of mental acuity and sharpness." Likewise an animal shares in the reason that a slave possesses, since all living things are born with some reason, as Plutarch has been at pains to show throughout his animal-related treatises and has allowed even the somewhat skeptical Soclarus to acknowledge at the beginning of the passage under discussion here (962A). If an animal possesses some reason, then it would seem to be entitled to the same consideration that must be accorded to the slave.

While Plutarch stops short here of specifying what constitutes the consideration that ought to be shown to a slave, and, in consequence, to animals, since they have a share of rationality in Plutarch's view, he enunciates the belief in a famous passage of his biography of the Roman statesman Cato the Elder, that at least kindness is owed to slaves. Moreover, he specifically links the necessity of showing kindness to slaves to a necessity of showing it to animals as well. When censuring Cato for selling off his old slaves when they were too old to be profitable, he remarks (Cato Maior 339) that he considers it the mark of a very harsh character to see no other tie between man and man than that of usefulness. Beneficence and kindness flow from a gentle heart, even to animals, and a good man will take care of his animals as of his worn-out slaves. Plutarch argues here as he had in his animal-related treatises: if one may defend those classes of human beings who cannot attain to the virtue of a Socrates, then one must defend animals who are not born to attain to perfect virtue any more than are those "marginal classes" of human beings like slaves.

The premises upon which the argument from marginal cases rests all find expression in Plutarch's discussion of humankind's relationship to animals: the idea that animals can to some extent reason and feel; the idea that such intellectual capacities in animals may equal or exceed those capacities in some classes of humans; and the idea that even defective classes of humans are entitled to some consideration, are clearly voiced in Plutarch's animal-related treatises. He comes closest to integrating these premises into a formulation of the argument from marginal cases in De sollertia animalium. In the final analysis, it must be admitted that his statement of the argument is not so succinct as that of Porphyry, ${ }^{19}$ nor does he specify in detail to what rights either the marginal cases of humans or animals might in fact be entitled. ${ }^{20}$ Yet Plutarch at least deserves credit for introducing into Greek speculation about the nature of humankind's relationship to other sentient beings a form of argument that continues to be employed by thinkers who seek to better the lot of animals, and for developing that argument with the logical rigor and compassion that distinguish the best literature of the modern movement for animal rights. 


\section{Notes}

${ }^{1}$ Brigid Brophy, "The Rights of Animals," London Sunday Times, October 10, 1965; reprinted in Brigid Brophy, Don't Never Forget: Collected Views and Reviews (New York 1966) 15-21.

2 Richard D. Ryder, Animal Revolution: Changing Attitudes Toward Speciesism (Oxford 1983) 3, 5-6, 183.

${ }^{3}$ Ryder's book, a historical survey of attitudes toward animals, accords a mere three pages (21-24) to the legacy of Mesopotamia, Greece and Rome. A noteworthy exception to the generalization that modern philosophers of animal rights are oblivious to the ancient contribution to the question is afforded by Daniel A. Dombrowski, The Philosophy of Vegetarianism (Amherst 1984), which contains a useful summary of Plutarch's attitudes toward animals (86-102) and ends with a helpful bibliography of works dealing with animal issues from antiquity to the present (167-183). In addition, philosopher Richard Sorabji, Animal Minds and Human Morals: The Origins of the Western Debate (Ithaca 1993), analyzes the extent to which the low esteem in which the mental capacities of animals were held by some ancient philosophers, in particular by Aristotle and the Stoics, has contributed to modern philosophic attempts to argue against the possession of rights by animals. Sorabji somewhat amusingly summarizes the Stoic opinion on animal intellect (2), "They don't have syntax, so we can eat them," an attitude still current among opponents of animal rights.

${ }^{4}$ Daniel A. Dombrowski, "Vegetarianism and the Argument from Marginal Cases in Porphyry," Joumal of the History of Ideas 45 (1984) 141-143, demonstrates that the argument can be detected in the third century in Porphyry's De abstinentia (On Abstinence from Animal Food). He restates his arguments substantially in "Porphyry and Vegetarianism: A Contemporary Philosophical Approach," Aufstieg und Niedergang der Römischen Welt 2, 36. 2 (1987) 774-777. In De abstinentia 3. 19, Porphyry argues that all rational humans who hold that unnecessary suffering ought to be spared all creatures must base their position on the assumption that those whose suffering they would remove possess sensation, and he holds that animals possess sensation as clearly as do human beings. Some classes of humans possess sensation but do not possess reason or intellect, but no human would wish to inflict suffering on them. Since animals can sense pain, is it not therefore just, Porphyry asks, that we spare them suffering as we do the defective humans?

${ }^{5}$ Scientific investigations of the intellectual capacities of animals abound in which these capacities are shown to compare favorably in some respects with those of humans possessing all of their intellectual capacities. Erick Eckholm, "Language Acquisition in Nonhuman Primates," in Animal
Rights and Human Obligations, ed. Tom Regan and Peter Singer (Englewood Cliffs 1989) 66-72, cites numerous examples of elaborate use of human sign language by chimpanzees, and he argues that while non-human primates have not been shown to speak human languages, they can understand human words and react appropriately to such languages through their own mastery of human sign language. Animal communication is treated at length in Donald R. Griffin, Animal Minds (Chicago 1992) 154-174, and in Rosemary Rodd, Biology, Ethics and Animals (Oxford 1992) 74-104.

${ }^{6}$ The formulation of the argument from marginal cases followed in this study is that of Peter Singer, Animal Liberation: A New Ethic for Our Treatment of Animals (New York 1975) 250-251. A detailed analysis of the moral implications of the argument from marginal cases and a critical review of formulations of the argument in recent philosophical literature may be found in Tom Regan, "An Examination and Defense of One Argument Concerning Animal Rights," Inquiry 22 (1979) 189-219; reprinted in Tom Regan, All That Dwell Therein (Berkeley 1982) 113-147. Opponents of the argument from marginal cases argue that it is invalid to defend the rights of animals on the analogy of the case of marginal or nonparadigmatic humans since such humans do not possess the attributes that are paradigmatic of being human. Still others contend that the marginal cases of humans do not in fact have rights, as Geoffrey Russell Grice, The Grounds of Moral Judgment (Cambridge 1967) 147-148, "It is an inescapable consequence of the thesis presented in these pages that certain classes cannot have natural rights: animals, the human embryo, future generations, lunatics and children under the age of, say, ten." According to Grice, this is so because such classes cannot enter into contracts with rational humans, that is, they cannot understand justice. This position, called "contractarianism" or "contractualism" in contemporary discussions of animal rights issues, has been taken up again recently in Peter Carruthers, The Animals Issue: Moral Theory in Practice (Cambridge 1992), whose arguments are directed specifically against Regan (see especially 21-24). The modern contractarian position is the direct descendant of the Stoic position outlined in the present study and opposed by Plutarch.

${ }^{7}$ Plutarch touched upon animal-related issues elsewhere in the Moralia. In De fortuna (On Fortune) 98C, he argues that only the possession of reason renders human beings superior to animals; in De tuenda sanitate praecepta (Precepts for Preserving Health) 131F, he recommends a vegetarian regimen on the grounds that the human body cannot easily digest animal food, and in De amore prolis (On the Love of Offspring) 493C-D, he observes that animals, unlike human beings, never exhibit excesses of behavior.

${ }^{8}$ The reasons for Plutarch's support of the vegetarian lifestyle have been investigated at length by recent scholars. 
The author of the earliest exhaustive treatment of vegetarianism in ancient literature, Johannes Haussleiter, Der Vegetarismus in der Antike (Berlin 1935) 212-228, while considering Plutarch's arguments to be largely derived from Academic and Pythagorean sources, concludes that Plutarch is original in defending animals against consumption by humans on the ground of their possession of reason. Urs Dierauer, Tier und Mensch in der Antike: Studien zur Tierpsychologie, Anthropologie und Ethik (Amsterdam 1977) 279-293, emphasizes Plutarch's natural sympathy for animals as the fundamental cause for his opposition to the eating of meat. Dombrowski, The Philosophy of Vegetarianism 86-102, refrains from assigning a sole reason for Plutarch's support of vegetarianism, but emphasizes more than do other scholars Plutarch's argument that meat eating is both unnatural and physically difficult for humans. More recently, Damianos Tsekourakis, "Pythagoreanism or Platonism and Ancient Medicine? The Reasons for Vegetarianism in Plutarch's 'Moralia'," Aufstieg und Niedergang der Römischen Welt 2, 36. 1 (1987) 366-393, concludes that Plutarch's views were shaped by his study of contemporary medical writers and by his belief that justice toward animals was possible. For a general summary of Plutarch's attitudes toward animal-related issues, see Stephen T. Newmyer, "Plutarch on Justice Toward Animals: Ancient Insights on a Modern Debate," Scholia: Natal Studies in Classical Antiquity, N. S. 1 (1992) 38-54.

${ }^{9}$ In De amore prolis 493B-494A, Plutarch makes a similar point, arguing that animals are more chaste than are humans because they engage in sexual intercourse only at specific times, and then only for the purpose of procreation. Nor do animals seek to have large families, he notes (493B), for the tax advantages that such families brought to selfish Romans! A fascinating study of the literary influence of the treatise Bruta animalia ratione uti is offered in G. Indelli, "Plutarco, Bruta Animalia Ratione Uti: Qualche Riflessione," in Plutarco e le Scienze, ed. I. Gallo (Genoa 1992) 317-352.

${ }^{10}$ Plutarch's hostility toward Stoicism has often been remarked upon by scholars, most especially in Daniel Babut, Plutarque et le Stoïcisme (Paris 1969), passim. Babut 54 argues that Plutarch's natural sympathy for animal creation necessarily placed him in opposition to the Stoics. Hubert Martin, "Plutarch's De Sollertia Animalium 959B-C: The Discussion of the Encomium on Hunting," American Journal of Philology 100 (1979) 104, argues that a general antipathy toward Stoicism is joined in De sollertia animalium with an attack on the Peripatetic view of animals.

11 All translations from Greek and Latin authors in this study are the author's own.

12 The fragments of Chrysippus on the animal soul are found in Johannes von Arnim, Stoicorum Veterum Fragmenta (Stuttgart 1905; reprinted 1964) 2. 714-716.
${ }^{13}$ On the Stoic doctrine of the self-interested nature of the animal, see Diogenes Laertius 7. 85: "They say that the first impulse of the animal is toward self-preservation."

${ }^{14}$ On the "governing principle" in Zeno, see von Arnim 1. 143; in Chrysippus, von Arnim 2. 827. The concept of the "governing principle" and its implications for animal behavior are well discussed in A. A. Long, Hellenistic Philosophy: Stoics, Epicureans, Sceptics (New York 1975) 171-174.

${ }^{15}$ The Greek text of the treatises of Plutarch followed in this study is that of Harold Cherniss and William C. Helmbold, Plutarch's Moralia XII (Cambridge 1957).

${ }^{16}$ In the introduction to their translation of De sollertia animalium, Cherniss and Helmbold 311 note, "There can be no doubt that Plutarch composed this pleasant work from commentarii derived not merely from Aristotle (mentioned specifically in $965 \mathrm{D}$ and quoted often), but also from various other compendia, seen in Aelian's and Pliny's natural histories and elsewhere." Much of their commentary on this and the other animal-related treatises of Plutarch is devoted to source hunting, and they provide extensive references to Plutarch's use of works by Aristotle, Plato, Theophrastus and others. Examples of studies of Plutarch's animal-related treatises that concentrate on isolation of Plutarch's sources are $O$. Dickermann, "Some Stock Illustrations of Animal Intelligence in Greek Psychology," Transactions of the American Philological Association 42 (1911) 123-130; V. d'Agostino, "Sulla Zoopsicologia di Plutarco," Archivo Italiano di Psicologia 11 (1933) 21-42; Konrat Ziegler's analysis of "die tierpsychologischen Schriften" of Plutarch in his Plutarchos von Chaironeia (Stuttgart $1964=$ Realenzyklopädie der Klassischen Altertumswissenschaft 21. 636-962) 96-108; and F. Becchi, "Istinto e Intelligenza negli Scritti Zoopsicologici di Plutarco," in Scritti in Memoria di Dino Pieraccioni, ed. M. Bandini and F. G. Pericoli (Florence 1993) 59-83. Few scholars who have examined the animal-related works of Plutarch have attempted to account for his interest in animals or have reflected on the accuracy of his observations. An exception is R. H. Barrow, Plutarch and His Times (London 1967), who shows greater appreciation for Plutarch's enthusiasm for animals than have most recent authors of general works on Plutarch. Barrow notes (116) that Plutarch's discussion of dolphins "... anticipates in small compass what is now being written about this animal." More recently, Kenneth J. Pratt, "Plutarch's Formal and Animal Psychology," in Panhellenica: Essays in Ancient History and Historiography in Honor of Truesdell S. Brown, ed. Stanley M. Burstein and Louis A. Okin (Lawrence, Kansas 1980) 171-186, while acknowledging his debt to d'Agostino, argues that Plutarch's deep humanity naturally led him to sympathy for animal creation.

${ }^{17}$ The motives that led Empedocles and Pythagoras to argue against the consumption of animal-derived foods are 
far from agreed upon by scholars. Empedocles seems to have believed that men during the Golden Age naturally spared animals because human natures were then more gentle and amiable; see, for example, Empedocles: The Extant Fragments, ed. M. R. Wright (New Haven 1981), fragment 119 (Diels-Kranz 130), with Wright's commentary, 284; more recently, Brad Inwood, The Poem of Empedocles (Toronto 1992) 60-61, interprets Empedocles' Golden Age theory and its implications for human behavior toward animals. In the case of Pythagoras, Tsekourakis 370-379 has shown that various beliefs contributed to Pythagoras' opposition to meat-eating, including his belief in metempsychosis and his notion that consumption of meat befouled the soul. Concern for animals as suffering creatures seems to have played little part in Pythagoras' doctrine, which sets him apart from Plutarch.

${ }^{18}$ Plutarch's treatise De Stoicorum repugnantiis (On Stoic Self-Contradictions) is a lengthy catalogue of contradictions detectable in Stoic doctrine, most especially in the works of
Chrysippus, whom Plutarch charges (1047B) with saying anything that occurs to him.

${ }^{19}$ See note 4 above.

${ }^{20}$ It might be noted that even Tom Regan, "An Examination and Defense of One Argument Concerning Animal Rights," passim, while offering an exhaustive defense of the proposition that animals are entitled to any rights to which marginal cases of humans are entitled, hesitates to specify what those rights might be. In The Case for Animal Rights (Berkeley 1983) 276280 , Regan argues that all moral agents and patients possess at least the right to respectful treatment, a point of view remarkably similar to that advanced in Plutarch's discussion of Cato's unfeeling treatment of his slaves and animals. Regan argues that according respectful treatment to marginal cases of humans will prevent persons from treating them as if they were receptacles of value without value of their own, for such a view would allow one to harm them by causing them suffering. Such behavior is, in the view of both Plutarch and Regan, morally wrong.

\section{Caterpillar}

I am born

And then, all at once,

The pale light of spring,

That has hung for my whole life

In the air like winter's breath,

Changes into gold.

And the warm hand of the sun,

Through the new leaves,

Falls trembling over me.

And beneath me, beneath the rough bark

I have known forever, the sleeping sap rises

Through the very skeleton of this tree.

It is then that I feel at my shoulders

An ache

That will pull me into air.
And so, even as the last clinging web,

Where I was born with a thousand others

To crawl across a tree,

Floats shining to the ground,

I twirl my silk around and around

Just me

Then sleep, then wake again, born and new.

Now in the hot sun, my wings

Like petals dry blue and butter

And suddenly, the whole world fills for me

With flowers,

The way the world must fill for you

With those stars you love, that sometimes,

On the darkest nights, step down.

And catch the wish you throw them.

Kathryn Winograd

Littleton, Colorado 